\author{
GRZEGORZ LISOWSKI ${ }^{1}$, PIOTR CHUDZIK ${ }^{1}$ \\ JERZY ZGRAJA ${ }^{2}$ \\ ${ }^{1}$ Politechnika Lódzka, Instytut Automatyki \\ ${ }^{2}$ Politechnika Lódzka, Instytut Informatyki Stosowanej
}

\title{
SYSTEM ZABEZPIECZEŃ WYSOKOCZĘSTOTLIWOŚCIOWEGO GENERATORA DO NAGRZEWANIA INDUKCYJNEGO
}

\begin{abstract}
$W$ artykule przedstawiono opis ukladu sterowania prototypowego generatora stużącego do nagrzewania indukcyjnego ze szczególnym naciskiem na elementy systemu zabezpieczeń. Układ ten sklada się z zaawansowanego systemu sterowania, umożliwiajacego automatyczna realizację różnorodnych procesów technologicznych oraz wychwytywanie wszystkich stanów awaryjnych $i$ reakcję na nie.
\end{abstract}

\section{WPROWADZENIE}

Układy sterowania we współczesnych urządzeniach przemysłowych mają za zadanie nie tylko realizację podstawowego celu działania, ale również muszą spełniać szeroko pojęte funkcje zabezpieczeń. Dobrze zaprojektowane powinny chronić przed nieprawidłową pracą urządzenia i zapewniać możliwość natychmiastowej reakcji w stanach, w których występuje zagrożenie zniszczenia sterowanych obiektów oraz samych wykonawczych elementów energoelektronicznych. W przypadku sterowania układami o dużej dynamice do zapewnienia bezpieczeństwa elementów wykonawczych nie wystarcza często jedynie samo kontrolowanie, czy nie zostały przekroczone wartości maksymalne dostępnych pomiarowo wielkości napięć, prądów lub temperatury. Niektóre urządzenia i obiekty sterowania wymagają obliczania w czasie rzeczywistym na przykład wartości dostarczonej do obiektu energii (na podstawie mierzalnych wielkości prądów i napięć) i jej ograniczania zanim nadmierny wzrost temperatury stanie się widoczny $\mathrm{w}$ postaci mierzonego sygnału temperatury lub zniszczenia urządzenia. Dla urządzeń falownikowych częstotliwości przełączeń dochodzące do dziesiątek i setek kiloherców sprawiają, że zjawiska podlegające kontroli i regulacji w systemach sterujących, rozpatrywane są $\mathrm{z}$ krokiem czasowym, sięgającym często pojedynczych mikrosekund. Wykonywanie $\mathrm{w}$ tak krótkich 
czasach pomiarów i algorytmów sterowania wymaga bardzo wydajnych systemów mikroprocesorowych lub układów logiki programowalnej. W Instytucie Informatyki Stosowanej Politechniki Łódzkiej powstaje prototyp układu generatora do grzania indukcyjnego w zakresie częstotliwości od kilku do $400 \mathrm{kHz}$, który w końcowej wersji będzie oparty na tranzystorach mocy typu $\mathrm{SiC}$ (na obecnym etapie projektu wykorzystywane są elementy IGBT, które pozwalają na efektywną pracę z częstotliwością sięgającą $100 \mathrm{kHz}$ ). Omawiany system generatora do nagrzewania indukcyjnego, składający się z układów sterowania, energoelektronicznych elementów mocy oraz obwodu rezonansowego ze wzbudnikiem uwzględnia różne aspekty zabezpieczeń związanych z samym urządzeniem, jak i podlegającym obróbce cieplnej wsadem.

\section{UKLAD STEROWANIA}

W opisywanym układzie prototypowym zastosowano rozbudowany system sterowania rozproszonego, oparty o procesor firmy Infineon $\mathrm{z}$ jądrem ARM Cortex-M4 i układ z logiką programowalną FPGA firmy Xilinx (rys. 1). Elementy te stanowią główny moduł sterowania, który bezpośrednio oddziałuje na układ mocy składający się z trzech osobnych bloków w postaci mostka $\mathrm{H}$ (falownik) $\mathrm{i}$ trzech niezależnych układów regulacji napięcia zasilającego falowniki (przetwornice typu BUCK). Bloki te, których struktura obwodu rezonansowego została oparta na topologii LCL, mogą od strony zasilania wzbudnika być połączone w sposób szeregowy lub równoległy, co daje większe możliwości dostosowania się generatora do obciążenia. Ze względu na potrzebę bardzo dokładnej znajomości wartości napięć i prądów w obwodach generatora dokonywany jest szybki pomiar tych sygnałów. Do realizacji zadań związanych z konfiguracją urządzenia, kontrolą wielkości wolnozmiennych oraz pomiaru temperatury radiatorów układów mocy i detekcji przepływu czynnika chłodzącego zastosowano układy peryferyjne sterowania przekaźnikowostycznikowego. Dodatkowymi elementami obwodów systemu generatora są sterowniki silników krokowych, za pomocą których moduł główny, poprzez zmianę położenia rdzeni, może dostosowywać wartości indukcyjności szeregowej Ls układu rezonansowego LLC. Dzięki temu uzyskuje się lepsze dopasowanie układu i wydajniejsze działanie generatora. W skład systemu wchodzi również, obsługiwany przez operatora, komputer PC, pełniący rolę nadrzędnego układu sterującego. Jego zadania polegają na ustaleniu ogólnych warunków procesu, takich jak zadawanie parametrów różnych testowych eksperymentów, początkowych ustawień samego procesu grzania oraz jego przebiegu na podstawie zdobytej wiedzy [1]. Układ nadrzędny realizuje również funkcję wizualizacji etapów działania całego systemu „on line”. W systemie znajduje się również specjalny element wizyjnego monitorowania (kamera CCD) obecności, rozmiarów i stanu wsadu. Cały proces grzania podzielono 
na etap identyfikacji parametrów obciążenia składający się z kilku różnych prób testowych, po których program komputera nadrzędnego pozwala na dobór parametrów układu wzbudnika, czyli wielkości kondensatora rezonansowego oraz ustaleniu parametrów startowych dla samego przebiegu grzania.

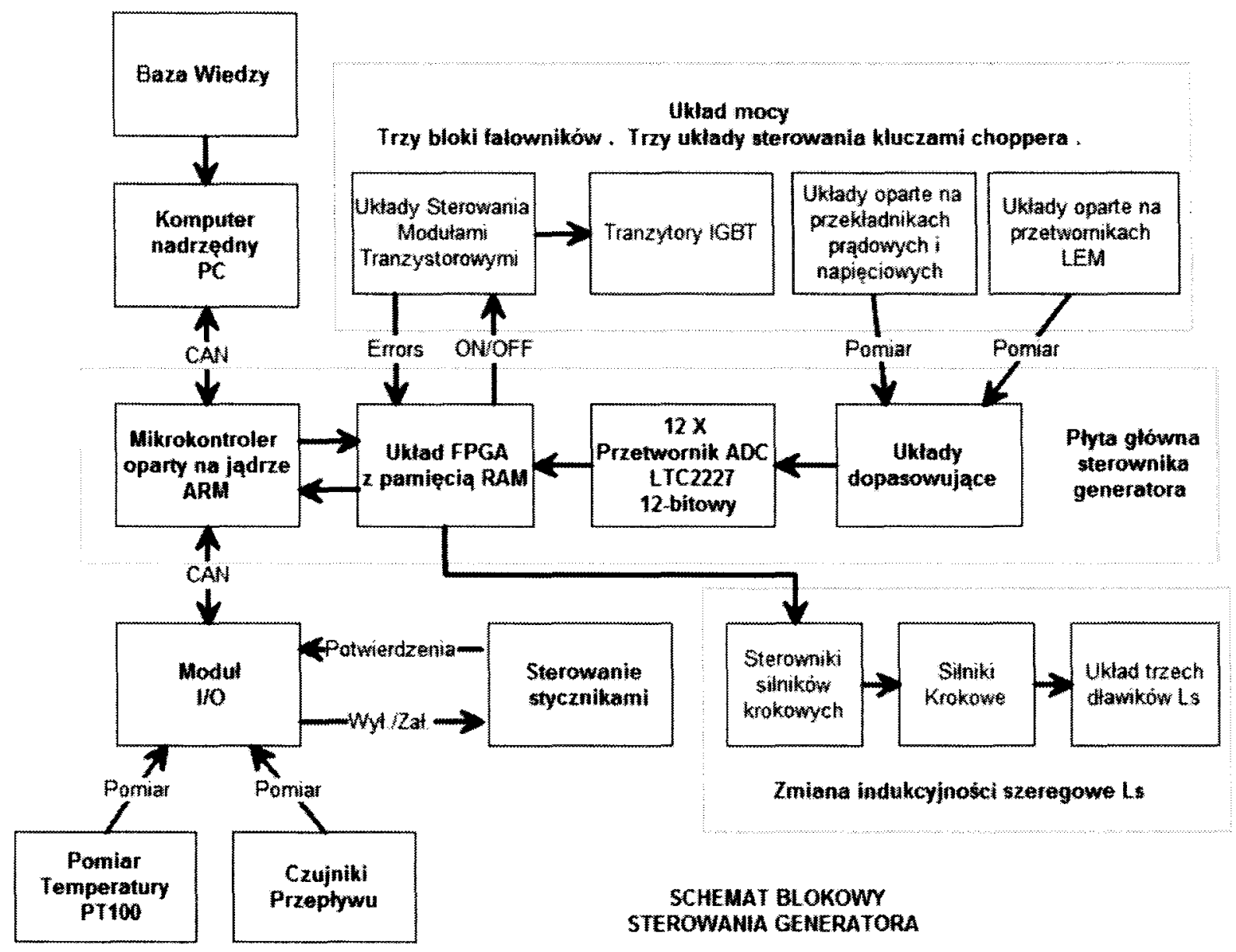

Rys. 1. Schemat ideowy systemu sterowania prototypowego generatora do nagrzewania indukcyjnego

Szczegółowe właściwości i zadania układu sterowania realizowane przez moduł główny to :

- szybki pomiar wartości analogowych (12 kanałów pomiarowych o rozdzielczości 12-bitów i częstotliwości przetwarzania od 40 Msps do 100 Msps),

- realizacja fali napięciowej o regulowanej amplitudzie w zakresie od $10 \mathrm{~V}$ do $500 \mathrm{~V}$ i częstotliwości od $5 \mathrm{kHz}$ do $100 \mathrm{kHz}$ (docelowo $400 \mathrm{kHz}$ ) w trzech blokach falownikowych, które mogą być połączone szeregowo lub równolegle,

- zmiana charakteru układu obciążenia poprzez zmianę wartości indukcyjności szeregowej Ls, w trakcie pracy generatora przy pomocy układów z silnikami krokowymi, a pośrednio również przez zmianę częstotliwości,

- realizacja strategii sterowania opartej o trzy kryteria: minimalizację strat mocy w układzie, uzyskanie mocy wyjściowej równej mocy zadanej oraz 
dopasowanie impedancji zastępczej obciążenia falownika do rezystancji znamionowej wynikającej z napięcia i prądu znamionowego,

- wymiana informacji z komputerem PC o wartościach wielkości zadanych i kontrolowanych $w$ cyklu grzania oraz o parametrach związanych $\mathrm{z}$ zadaniem monitorowania procesu,

- realizacja sterowania zdalnego układów stycznikowych poprzez dodatkowy moduł $\mathrm{I} / \mathrm{O}$,

- realizacja pomiaru temperatury radiatorów i przepływu czynnika chłodzącego wykorzystująca moduł I/O i transmisję opartą o interfejs CAN,

- realizacja automatu stanu programu głównego, który uwzględnia wszystkie etapy sterowania, jakie mogą wystąpić w trakcie działania generatora (rys. 2),

- analiza mierzonych sygnałów i szacowanie energii strat w układzie,

- reakcja na stany ostrzegawcze $\mathrm{i}$ alarmowe wynikające $\mathrm{z}$ sygnałów analogowych i cyfrowych,

- realizacja obliczeń modułu i fazy pierwszej harmonicznej prądów bloków falowników oraz napięcia na kondensatorze rezonansowym oraz obliczeń szacujących energię dostarczaną do układu obciążenia - wsadu.

Realizacja algorytmów związanych z trzema ostatnimi punktami rozumiana jest jako system zabezpieczeń $w$ układzie sterowania.

Tabela 1. Opis sygnałów występujących na rys. 2

\begin{tabular}{|c|l|}
\hline Nazwa sygnału & \multicolumn{1}{|c|}{ Opis sygnałów } \\
\hline CZAS.START & Czas oczekiwania na uruchomienie podzespołów \\
\hline FPGA.READY & Potwierdzenie uruchomienia układu FPGA \\
\hline W.P.K & Warunek poprawnej kalibracji \\
\hline R.Ł & Rozkaz ładowania \\
\hline P.Ł & Potwierdzenie ładowania \\
\hline C.Ł & Czas ładowania \\
\hline P.G & Potwierdzenie gotowości \\
\hline W.STOP & Warunek zatrzymania pracy układu \\
\hline R.START & Rozkaz startu \\
\hline W.E.1...7 & Warunki błędów \\
\hline R.N.K & Restart kalibracji \\
\hline W.N.K & Warunek nieprawidłowej kalibracji \\
\hline
\end{tabular}


System zabezpieczeń wysokoczęstotliwościowego generatora...

\begin{tabular}{|c|l|}
\hline R.B & Reset blokowania \\
\hline W.K & Warunek blokowania \\
\hline B.E+CZAS.E & Brak warunku błędu \\
\hline C.R & Czas rozładowania \\
\hline
\end{tabular}

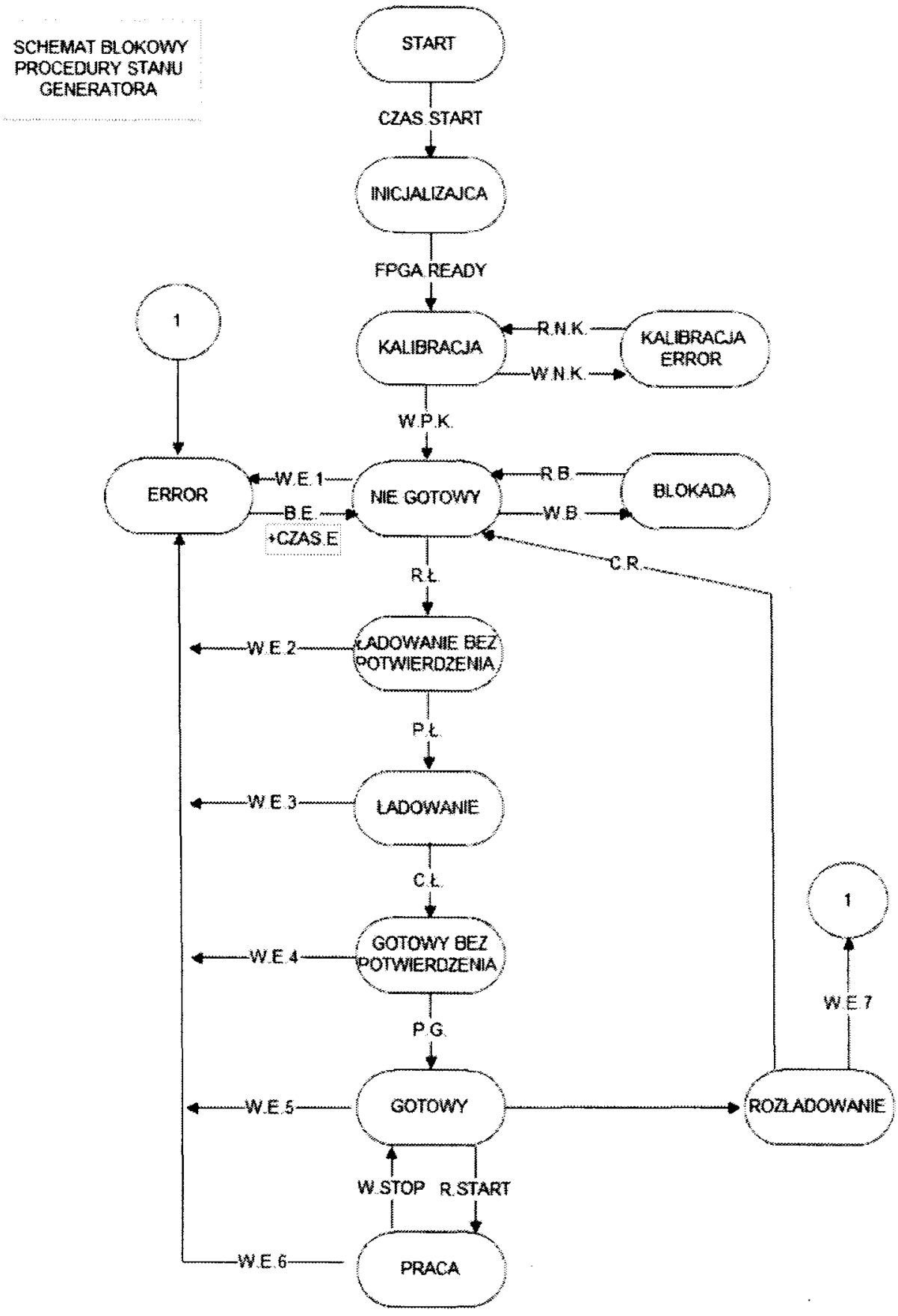

Rys. 2. Schemat blokowy algorytmu stanu w prototypowym generatorze 


\section{ELEMENTY ZABEZPIECZEŃ}

\section{Test konfiguracji systemu}

System zabezpieczeń składa się z kilku różnych elementów. Pierwszy element - nadrzędny, analizujący poprawną konfigurację układu sterowania, składa się z dwóch etapów:

- detekcji poprawnego załadowania struktury FPGA ( FPGA.READY),

- pomiaru wszystkich sygnałów analogowych i wyznaczeniu tak zwanych „offsetów" - wartości pomiarowych ustalających punkty odniesienia zera dla każdego kanału. Jeżeli wartości te przekraczają 10\% zakresu pomiarowego uznaje się, że układ nie nadaje się do pracy (warunek nieprawidłowej kalibracji). Należy wtedy sprawdzić układ pomiarowy i ponowić kalibrację.

Drugi element systemu zabezpieczeń dotyczy sygnałów, które dostarczane są do procesora drogą komunikacji po interfejsie CAN z modułów wejściawyjścia. Sygnały te określone są jako wolne i reakcja na nie nie jest krytyczna czasowo. Zawierają one informacje o konfiguracji styczników wejściowych, o temperaturach radiatorów bloków falowników oraz przepływie i temperaturze czynnika chłodzącego. Analiza konfiguracji styczników (potwierdzenie ładowania oraz potwierdzenie gotowości) występuje przede wszystkim na etapie załączania generatora do sieci zasilającej $3 * 400 \mathrm{~V}$. Najpierw realizowane jest wstępne ładowanie kondensatorów wejściowych przez rezystory, a następnie włączenie zasilania bezpośrednio do układu falownika.

\section{Kontrola temperatur elementów chlodzenia}

Sygnały temperaturowe dostarczane przez układ I/O porównywane są z dwoma ustawieniami - progami, które wyznaczają stan ostrzegawczy i stan awaryjny. Detekcja przekroczenia pierwszego progu nie przerywa procesu grzania bezpośrednio w układzie sterowania, tylko zgłaszana jest komputerowi nadrzędnemu, co może skutkować ograniczeniem mocy lub przerwaniem grzania po interwencji operatora. Przekroczenie temperatury drugiego progu, wyłącza falownik jako stan awaryjny, chroniąc układy mocy przed zdegenerowaniem. Potwierdzenie przepływu czynnika chłodzącego też jest ważnym elementem zabezpieczeń i występuje jako jeden z warunków błędów. Gdy brak jest chłodzenia układów mocy generator nie powinien pracować.

\section{„Szybkie” zabezpieczenia związane z sygnałami analogowymi i działaniem tranzystorów}

Główny system zabezpieczeń oparty jest o sygnały wytwarzane i mierzone w układzie mocy, którego ogólny schemat przedstawiono na rys. 3 . 


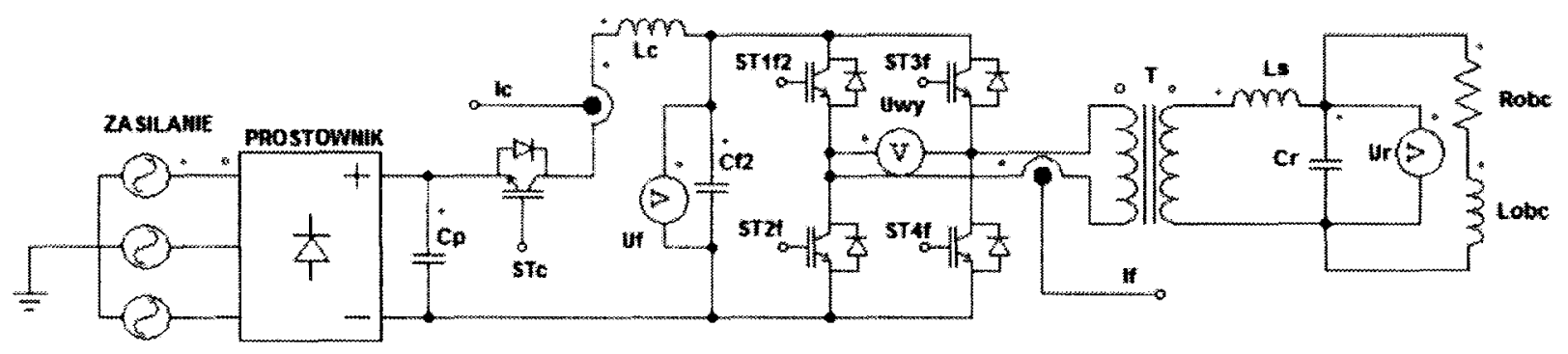

Rys. 3. Schemat ideowy obwodu mocy jednego bloku falownikowego

Układem, który w szybki sposób realizuje funkcję zabezpieczeń w przypadku nieprawidłowych, nadmiarowych sygnałów prądowych i napięciowych jest układ logiki programowalnej (FPGA) w powiązaniu $\mathrm{z}$ dwunastoma szybkimi przetwornikami analogowo-cyfrowymi $z$ przetwarzaniem potokowym, pracującymi z częstotliwością $40 \mathrm{MHz}$ (docelowo do $100 \mathrm{MHz}$ ). System ten mierzy prąd $I c$, napięcie falownika $U f$, prąd falownika If każdego z bloków oraz napięcie $U r$ na kondensatorze $\mathrm{Cr}$ w obwodzie rezonansowym. System reaguje natychmiast na wartości poza dopuszczalnym zakresem pomiarowym przetwornika A/D, wykrywając jego sygnał Over/Under-flow Output, jak również realizuje funkcję komparatora cyfrowego, porównując pomierzone sygnały $\mathrm{z}$ wartościami uznanymi za niebezpieczne. Reakcja powoduje wyłączenie wszystkich łączników oraz odcięcie od sieci zasilającej bloków falowników. Należy zwrócić uwagę, że zabezpieczenie od komparatora jest opóźnione w stosunku do rzeczywistego przekroczenia wartości danego sygnału, gdyż przetwarzanie potokowe powoduje pojawienie się danej pomiarowej 5 cykli zegara później w stosunku do sygnału na wejściu przetwornika.

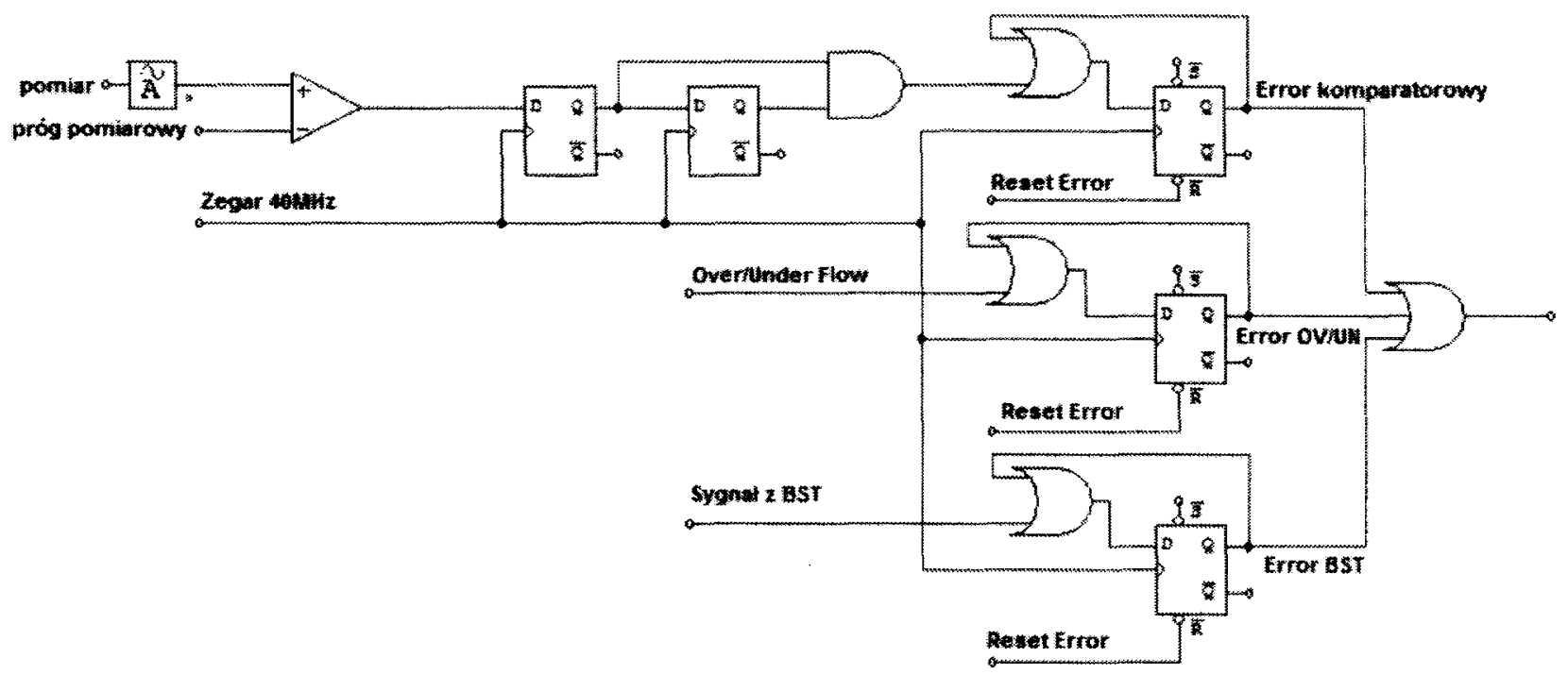

Rys. 4. Poglądowy schemat zabezpieczeń sygnałów „szybkich”

W układzie dodatkowo zastosowano prosty filtr cyfrowy, który eliminuje chwilowe lub zakłóceniowe składowe sygnału przekraczające wartości 
bezpieczne. Układ FPGA reaguje również na sygnały błędów układów BST Basic Switching Transistor wyzwalających aktywną pracę łączników, które wykrywają nieprawidłową pracę tych układów np. związaną z zanikiem napięcia zasilania. Układ z logiką programowalną zapamiętuje błędy, blokując falowniki do czasu reakcji procesora ARM, który po analizie tych sygnałów resetuje wszystkie błędy (rys. 4).

\section{DYNAMICZNE ZABEZPIECZENIE TERMICZNE STRUKTUR TRANZYSTORÓW}

Wartości katalogowe dopuszczalnych prądów współczesnych elementów energoelektronicznych pokazują, że prąd maksymalny, jaki w sposób krótkotrwały może płynąć w strukturze półprzewodnika jest wielokrotnie większy od prądu, jaki może płynąć w elemencie w sposób ciągły. Przyczyną tej rozbieżności jest ograniczona zdolność oddawania ciepła powstającego w strukturze podczas przewodzenia prądu oraz podczas procesu przełączania. Zwykle podczas projektowania układu uwzględnia się oba rodzaje strat i dobiera się elementy według zasady najgorszego przypadku. W typowych strukturach przetwornic czy falowników wystarczy w tym celu znać maksymalną częstotliwość przełączania, określić czy układ ma charakter pojemnościowy, czy indukcyjny oraz wyznaczyć najwyższe prądy, które bywają w układzie załączane i wyłączane. W przypadku urządzeń wykorzystujących zjawisko rezonansu zwykle można pominąć, bądź bardzo ograniczyć, starty związane z przełączaniem prądów, dzięki możliwości wykonywania przełączeń w stanie zerowego napięcia lub prądu. Tego typu rozwiązania $\mathrm{z}$ powodzeniem stosuje się w rezonansowych przetwornicach DC/DC.

$\mathrm{Na}$ rysunku 5 zamieszczono przebieg napięcia na wyjściu falownika oraz prądu płynącego $\mathrm{w}$ obwodzie $\mathrm{w}$ stanie rezonansu (przełączanie odbywa się bezprądowo) oraz w stanie pracy bliskim rezonansu (przełączanie tranzystorów przy niezerowym prądzie). Wykorzystanie zjawiska rezonansu w przypadku układów nagrzewania indukcyjnego nie jest już takie łatwe. $O$ częstotliwości rezonansowej decyduje bowiem nie tylko obwód LC składający się z dławika i kondensatora o stałych wartościach, ale struktura złożona ze wzbudnika i wsadu, których parametr indukcyjności jest silnie zmienny $w$ funkcji temperatury [2]. 
a)

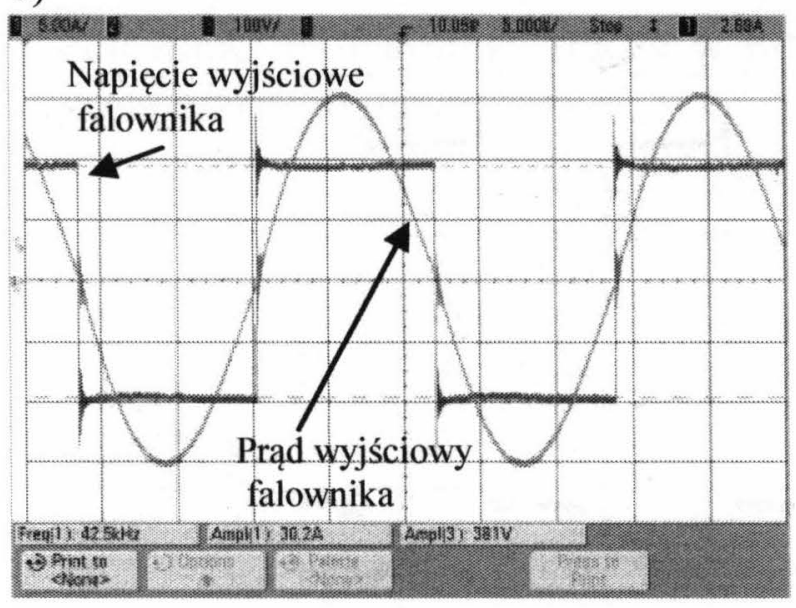

b)

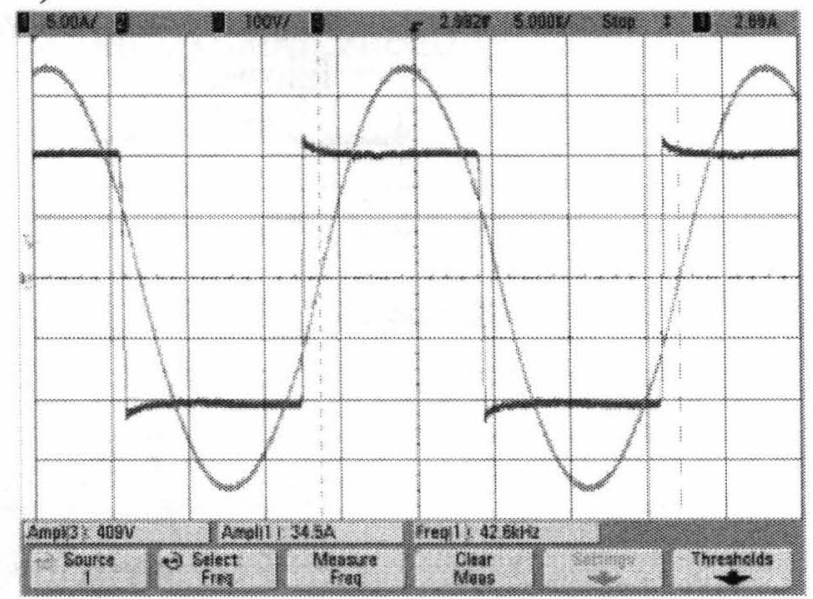

Rys. 5. Przebieg napięcia wyjściowego falownika i prądu w uzwojeniu pierwotnym generatora w przypadku rezonansu (a) i w przypadku pracy z częstotliwością odbiegającą od rezonansowej (b)

Utrzymanie w tego typu układzie częstotliwości przełączeń, zapewniającej komutacje w chwilach „przechodzenia” prądu przez zero wymaga bardzo dokładnego kontrolowania czasów załączania i wyłączania tranzystorów. Dodatkowym utrudnieniem dla systemu sterowania jest, występujący w omawianym generatorze, złożony układ rezonansowy o wyższym niż zwykły obwód LC rzędzie. Ze względu na złożoną dynamikę zjawisk zachodzących w takim układzie przekształtnik-wzbudnik-wsad niekiedy niemożliwe jest uzyskanie w całym przebiegu grzania „miękkiego” (bezprądowego) przełączania tranzystorów.

$\mathrm{Na}$ rysunku 6 przedstawiono oscylogram pokazujący start pracy generatora z częstotliwością odpowiadającą częstotliwości rezonansowej w stanie ustalonym (oscylogram górny) oraz przebieg pokazujący możliwość wystąpienia niesymetrycznej fali prądowej (oscylogram dolny), gdzie jedno z przełączeń odbywa się bezprądowo, a drugie przy prądzie niezerowym. Każde odstępstwo od bezprądowego przełączania wiąże się $\mathrm{z}$ natychmiastowym wzrostem mocy strat wydzielanych $\mathrm{w}$ strukturze półprzewodników, $\mathrm{z}$ których jest zbudowany przekształtnik. Uwzględnienie tych zjawisk na etapie projektowania i doboru układu tranzystorów i systemu chłodzenia w kategoriach najgorszego przypadku prowadzi do znacznego przewymiarowania układu, a co za tym idzie i nieuzasadnionego wzrostu jego ceny. Aby tego uniknąć, autorzy projektu podjęli decyzję o zbudowaniu systemu zabezpieczania modułów tranzystorowych za pomocą wprowadzenia modelu cieplnego struktury tranzystorów. 

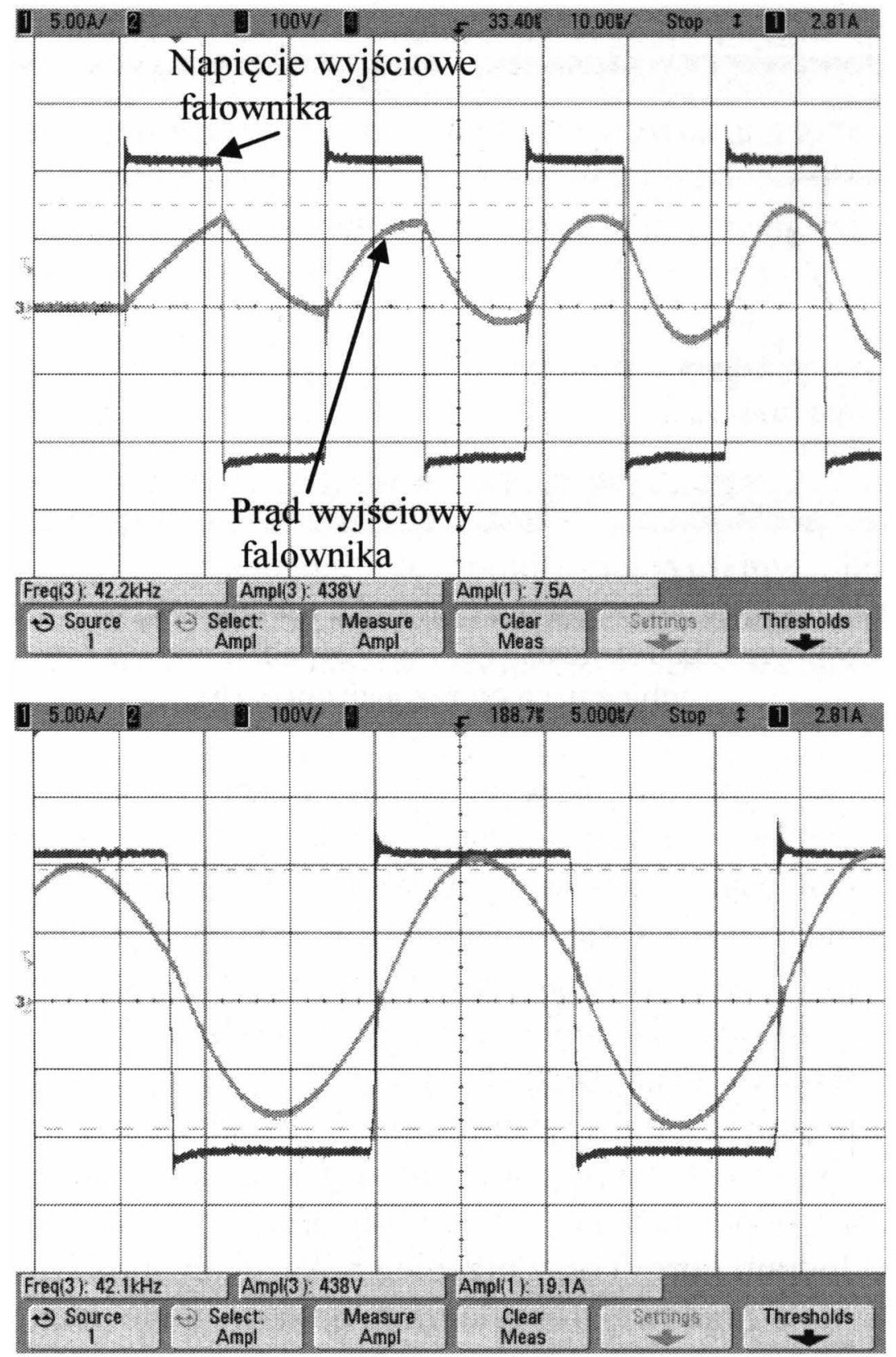

Rys. 6. Przebieg napięcia wyjściowego falownika i prądu w uzwojeniu pierwotnym generatora w przypadku startu pracy układu (górny oscylogram) i w przypadku pracy z niesymetryczną falą prądową (dolny oscylogram)

Do wyznaczenia tego modelu użyto danych producenta modułów tranzystorowych, zamieszczonych $\mathrm{w}$ nocie katalogowej $\mathrm{w}$ postaci wykresu „impedancji termicznej” dla różnych stałych czasowych [3]. Tak sparametryzowany przez producenta model pozwala na określenie przyrostów temperatury w stanach dynamicznych, w których zasadniczą rolę odgrywa pojemność cieplna struktury wewnętrznej tranzystora. Zaproponowane rozwiązanie umożliwia pośrednio kontrolę stanu termicznego struktur w oparciu o wyznaczone w czasie rzeczywistym, na podstawie mierzalnych wartości prądów i napięć, aktualnych wartości energii strat powstających w tranzystorach 
na skutek przełączania prądów. Na rysunku 7 zamieszczono przykładowy zapis modelowanej temperatury złącza w przypadku dynamicznego procesu regulacji podczas rozruchu generatora.



Rys. 7. Przebieg modelowanej na podstawie strat przełączeń temperatury struktury

wewnętrznej tranzystora w stanie nieustalonym, w którym występowały liczne (przy znacznym, niezerowym prądzie) tak zwane ,twarde” przełączania tranzystorów

\section{ZABEZPIECZENIE WSADU}

Urządzenia do nagrzewania indukcyjnego powinny mieć możliwość zabezpieczenia wsadu za pomocą układu ograniczania dostarczanej do niego energii. Szczególnie ważne jest to w systemach przeznaczonych do prowadzenia prac badawczych oraz w urządzeniach, które mogą wykonywać proces nagrzewania na niekoniecznie znanym, dobrze określonym wsadzie. Jak wspomniano wcześniej, każdy proces grzania ma składać się z dwóch etapów. Pierwszy jest etapem identyfikacji wsadu $\mathrm{i}$ właśnie $\mathrm{w}$ nim przewidziano zabezpieczenie oparte na pomiarze energii. Komputer nadrzędny na podstawie wiedzy zgromadzonej $\mathrm{w}$ bazie danych lub na podstawie danych podanych przez operatora określa ile energii można dostarczyć w poszczególnych testach identyfikacyjnych, tak by wsad po pierwsze nie został zniszczony, po drugie by jego temperatura nie wzrosła na tyle, by określać go jako wsad „zimny” przed następnym testem. Pomiar, a właściwie szacowanie wartości dostarczonej energii w systemie, w którym występują bardzo duże moce bierne jest dość skomplikowane. Zostało ono oparte o szybkie przetworniki i układ FPGA. W logice programowalnej zrealizowano układ archiwizowania danych pomiarowych pobieranych jednocześnie z 12 kanałów, synchronicznie do działania falownika. Co cykl pomiarowy wynoszący 1 milisekundę procesor wydaje rozkaz zapisania 256 próbek dla każdego kanału w pamięci RAM zaaplikowanej w układzie programowalnym. Struktura logiczna została tak opracowana, 
by zapisywane próbki były równo rozłożone w czasie $\mathrm{i}$ by ich liczba na jeden pełny okres działania falownika była 64 . Następnie informacje z pamięci RAM przesyłane są do procesora i tam następuje szacowanie energii na podstawie wzorów 1, 2, 3 określonych $\mathrm{w}$ tym wypadku dla równoległego połączenia bloków falowników. Założono, że dostarczana moc w ciągu 1 milisekundy niewiele się zmienia.

$$
\begin{gathered}
E_{T j}=\frac{\sum_{i=0}^{255} k \cdot\left(I_{f 1 i}+I_{f 2 i}+I_{f 3 i}\right) \cdot U_{r i} \cdot \frac{1}{64 \cdot f_{f}}}{4} \\
E_{1 m j}=l_{o k j} \cdot E_{T j} \\
E_{C}=\sum_{j=1}^{j} E_{1 m j}
\end{gathered}
$$

gdzie:

$k$ - przekładnia transformatora,

$\boldsymbol{i}$ - kolejna próbka sygnału w cyklu pomiarowym,

$I_{f}$ - prądy poszczególnych bloków,

$U_{r}$ - napięcie na kondensatorze rezonansowym,

$f_{f}$ - częstotliwość pracy falownika,

$E_{l m s}$ - szacowana energia w cyklu pomiarowym,

$E_{T j}$-szacowana energia za jeden okres w danym cyklu pomiarowym,

$l_{o k}$ - liczba okresów w danym cyklu pomiarowym,

$E_{C}$ - szacowana energia po j-tym cyklu pomiarowym.

Jeżeli $E_{C}$ przekroczy wartość maksymalnej energii wyznaczonej przez komputer nadrzędny, układ przerywa eksperyment, informując o błędzie. W przeciwnym przypadku informacja o energii przekazywana jest do komputera nadrzędnego, który decyduje o przebiegu następnych testów.

\section{PODSUMOWANIE}

W omawianym prototypowym układzie sterowania generatora do nagrzewania indukcyjnego zaaplikowano, uruchomiono i przetestowano większość omawianych aspektów zabezpieczeniowych. Część $\mathrm{z}$ nich jest w fazie testów końcowych. Kluczowym dla realizacji niektórych funkcji generatora jest zastosowanie szybkich przetworników analogowych i układu o logice programowalnej, który umożliwia jednoczesny zapis wielu sygnałów pomiarowych $\mathrm{z}$ bardzo dużą częstotliwością. Pomiary przekazane do układu mikroprocesorowego umożliwiają zrealizowanie wielu skomplikowanych 
funkcji obliczeniowych umożliwiających efektywniejsze sterowanie oraz pozwalają na zastosowanie dodatkowych funkcjonalności w układzie zabezpieczeń.

\section{LITERATURA}

[1] Kucharski J., Frączyk A., Urbanek P., Jaworski T.: Projekt inteligentnego generatora w.cz. do indukcyjnego nagrzewania wsadów, Przegląd Elektrotechniczny, R. 90, Nr 2, 2014, ss. 20-23.

[2] Kobos W., Zgraja J., Chudzik P.: ,Analysis of dual-frequency generators structures for induction heating, Materiały konferencji:HES-13. International Conference on Heating by Electromagnetic Sources. Induction, Dielectric and Microwaves, Conduction and Electromagnetic Processing. Padwa 2013, pp. 261-268.

[3] Nota katalogowa modułu tranzystorowego CAS300M12BM2: CAS300M12BM2 1.2-kV, 5.0-m $\Omega$, All-Silicon Carbide, Half-Bridge Module, update :03 Sep 2014, www.cree.com

Praca finansowana ze środków NCBiR $w$ ramach projektu Badań Stosowanych, nr umowy PBS1/A4/2/2012.

\section{PROTECTION SYSTEM IN HIGH FREQUENCY GENERATOR FOR INDUCTION HEATING}

\section{Summary}

The paper describes a prototype generator control system used for induction heating with particular emphasis on the elements of the protection system. This system consists of an advanced control system, enabling automatic implementation of various technological processes and capture all faults and react to them.

Keywords: induction heating, inverter, protection system. 